\title{
A hermenêutica da fé segundo Joseph Ratzinger
}

Orientador: Antonio Luiz Catelan Ferreira

Mestrando: Thadeu Lopes Marques de Oliveira

Área de Concentração: Teologia Sistemático-Pastoral

Linha de Pesquisa: Fé e Cultura

Projeto de Pesquisa: A teologia de Joseph Ratzinger - Bento XVI

A hermenêutica bíblico-teológica situada na metodologia teológica de Joseph Ratzinger, nomeada por ele hermenêutica da fé, é o tema principal dessa dissertação. Busca-se através desse aspecto do pensamento de Ratzinger encontrar perspectivas que proporcionem, no fazer teológico, uma relação saudável e frutífera entre Sagrada Escritura e teologia sistemática, tendo em vista o contexto da teologia contemporânea e os desafios hodiernos. Para analisar esse aspecto do pensamento de Ratzinger, foi necessário estudar e apresentar o que é o método histórico-crítico, pois a formulação da sua hermenêutica bíblico-teológica se deu no diálogo com ele. Posteriormente se analisou a importância da Constituição Dogmática Dei Verbum na sistematização da hermenêutica bíblico-teológica de Ratzinger. Buscando verificar esse aspecto de sua metodologia em uma área específica de sua teologia, optou-se pela cristologia, em especial no primeiro volume de sua obra Jesus de Nazaré. Nesse capítulo busca-se evidenciar a maneira como Ratzinger interpreta as Sagradas Escrituras no fazer teológico, com o objetivo de verificar se ele pratica sua hermenêutica bíblico-teológica. Também é dedicado um capítulo à apresentação das diversas análises feitas por alguns autores à proposta metodológica de Ratzinger para a composição do Jesus de Nazaré. Nessas análises, buscou-se focar a metodologia usada por Ratzinger. Foram apresentadas as recepções positivas, e também, algumas críticas.

Palavras-chave: Bíblia. Exegese. Cristologia. 